\title{
Manajemen Anestesi pada Seksio Sesarea dengan Preeklamsia Berat dan Morbid Obese
}

\author{
RTH Supraptomo', Yusmein Uyun ${ }^{2}$ \\ ${ }^{1}$ Peserta didik Subspesialis Anestesi Obstetri Anestesiologi dan Terapi Intensif Fakultas Kedokteran Kesehatan \\ Masyarakat dan Keperawatan Universitas Gajah Mada-RSUP Dr Sardjito Yogyakarta, ${ }^{2}$ Konsultan Anestesi Obstetri \\ Departemen Anestesiologi dan Terapi Intensif Fakultas Kedokteran Kesehatan Masyarakat dan Keperawatan \\ Universitas Gajah Mada-RSUP Dr Sardjito Yogyakarta ${ }^{2}$
}

\begin{abstract}
Abstrak
Pendahuluan: Preeklampsia adalah terjadinya trias preeklampsia (hipertensi, hipoalbuminemia, dan edema) yang mendadak setelah 20 minggu kehamilan. Pasien obesitas memiliki banyak implikasi klinis dalam tatalaksana anestesi. Kasus: Wanita, 22 tahun G2P1A0 hamil 39 minggu dengan preeklampsia berat, KPD 12 jam, obesitas morbid akan dilakukan seksio sesarea emergency dengan status fisik ASA IIIE, dilakukan pembiusan dengan teknik regional anestesi subarachnoid block dengan puncture di L3-L4 median, menggunakan agen levobupivakain $15 \mathrm{mg}$ dan fentanyl $25 \mathrm{mcg}$. Operasi berlangsung selama 1 jam 15 menit, dengan perdarahan $350 \mathrm{cc}$, hemodinamik stabil. Lahir bayi laki-laki, BB 3400 gr, APGAR Score 8-9-10. Diskusi: Preeklampsia adalah penyakit multiorgan yang spesifik terhadap kehamilan manusia, namun etiologi spesifik yang mendasari tetap belum diketahui. Tatalaksana bersifat suportif, melahirkan bayi dan plasenta tetap menjadi satu-satunya terapi definitif. Pasien obesitas memiliki banyak implikasi klinis untuk dipertimbangkan. Pemahaman mengenai patofisiologi akan membantu memberikan tatalaksana anestesi yang lebih baik. Simpulan: Pemilihan teknik neuraksial anestesi lebih direkomendasikan karena menghindari kemungkinan intubasi sulit pada kasus emergensi, perfusi uteroplasenta yang lebih baik, kualitas analgesi/anestesia yang baik, mengurangi obat yang masuk ke sirkulasi uteroplasenta, menurunkan stress operasi, dan psikologis ibu yang dapat melihat bayinya saat dilahirkan.
\end{abstract}

Kata kunci: neuraksial; obesitas; preeklampsia

\section{Anesthesia Management in Caesarean Section with Severe Preeclampsia and Morbid Obese}

\begin{abstract}
Introduction: Preeclampsia is a sudden triad of preeclampsia (hypertension, hypoalbuminemia and edema) after 20 weeks of pregnancy, Obese patients have many clinical implications to consider. Case: Female, 22 years old with G2P1A0, 39 weeks pregnant with severe preeclampsia, 12 hours PROM, pro morbid obesity SCTP-E with ASA IIIE physical status. Labor pain management was carried out using regional subarachnoid block anesthesia technique with puncture in median L3-L4, clear CSF (+), blood (-) using levobupivacaine 15 mg + fentanyl 25 mcg. The operation lasted for 1 hour 15 minutes, with $350 \mathrm{cc}$ bleeding, hemodynamically stable. Born a baby boy, BW 3400 gr, APGAR Score 8-9-10. Discussion: Preeclampsia is a multiorgan disease that is specific to human pregnancy, and the underlying specific etiology remains unknown. Management is supportive, giving birth to the baby and placenta remains the only definitive therapy. Obese patients have many clinical implications to consider. Understanding of pathophysiology will help provide better anesthesia management. Conclusion: The neuraxial anesthesia technique is recommended to avoids the possibility of difficult intubation, better uteroplacental perfusion, good analgesia / anesthesia quality, reducing drugs that enter the uteroplacental circulation, decreasing surgical stress, and maternal psychological to be able to see the baby at birth.
\end{abstract}

Key words: obesity; neuraxial; preeclampsia 


\section{Pendahuluan}

Komplikasi hipertensi tercatat 6-8\% pada kehamilan dan menjadi kontributor yang signifikan morbiditas dan mortalitas maternal dan perinatal. Di Amerika serikat preeklamsia menjadi satu dari tiga besar penyebab utama kematian ibu hamil. Penanganan yang tidak sesuai dengan standart, sering menjadi penyebab utama yang menyebabkan peningkatan morbiditas dan mortalitas pada ibu hamil. ${ }^{1-3}$ Seperti kita ketahui bahwa pre-eklamsia adalah terjadinya trias pre-eklamsia (hipertensi, hipoalbuminemia, dan edema) yang mendadak pada kehamilan setelah 20 minggu, sedangkan eklamsia adalah pre-eklamsia berat yang diikuti dengan kejang dimana sebelumnya tidak terjadi gangguan neurologis. Terapi utama yang harus dilakukan adalah melakukan terminasi kehamilan tersebut, hal ini akan memberikan pilihan yang sulit bagi dokter spesialis anestesi khususnya, oleh karena itu pemahaman fisiopatologis harus diketahui secara cermat dan teliti. ${ }^{2,4}$

Dengan memahami fisiopatologis dari preeklamsia ini sangat berkaitan sekali dengan kepentingan bagi anestetis. Yang mana menjadi modal awal sebelum memilih apakah akan melakukan dengan regional atau general anestesia untuk melakukan terminasi kehamilan pada pasien dengan pre-eklamsia berat. Kalaupun dengan regional anestesi maka apakah menggunakan spinal anestesi ataukah dengan epidural anestesi. Hal ini menjadi pilihan untuk kepentingan keselamatan bagi janin maupun ibu. ${ }^{1,2,4}$ Pre-eklamsia merupakan komplikasi kehamilan yang dapat menjadi kegawatan pada waktu timbul gejala-gejala neurologis, seperti nyeri kepala yang menetap dan berat, kebutaan dan kejang, disertai dengan hipertensi dan proteinuria pada akhir kehamilan, Kejadian yang bisa menjelaskan gejala neurologis pre-eklamsia berat dan eklamsia adalah adanya syndrome encephalopathy posterior yang reversible pada saat terjadi kenaikan tekanan darah. Kondisi ini terjadi pada pre-eklamsia yang disebabkan oleh gagalnya autoregulasi, bocornya sawar darah otak dan masuknya protein dan serum yang rusak ke jaringan otak. ${ }^{3-6}$

\section{Kasus}

Pasien wanita 22 tahun, merasa hamil 39 minggu, anak pertama, gerakan janin masih dirasakan. Perut dirasakan kenceng-kenceng hilang timbul $(+)$, air kawah ngrembes (-), lendir darah (-), pusing $(+)$, pandangan kabur(-), sesak nafas $(-)$, nyeri dada $(-)$, nyeri ulu hati $(-)$, mual $(+)$, muntah (-), demam (-). Laboratorium didapatkan Hb 12.2 Hct 26 proteinuria +2 , lain-lain dalam batas normal. Pasien didiagnosa dengan G2P1A0 hamil 39 minggu dengan preeklampsia berat, KPD 12 Jam, obesitas morbid pro SCTP-E dengan status fisik ASA IIIE. Pasien dengan riwayat mengorok, dan lingkar leher $>41 \mathrm{~cm}$, BMI 40.07. Telah diberikan MgSO4 20\% 4 gram SP (inisial) di lanjutkan MgSO4 20\% 1gr/jam dalam 24 jam dan nifedipin 3x10 mg per oral. Pasien dipremedikasi dengan metochlorpramide $10 \mathrm{mg} / \mathrm{IV}$ dan ranitidin $50 \mathrm{mg} / \mathrm{IV}$. Dilakukan manajemen anestesi persalinan dengan teknik regional anestesi subarachnoid block dengan puncture di L3-L4 median, LCS (+) jernih, darah (-) menggunakan agen levobupivakain $15 \mathrm{mg}+$ fentanyl $25 \mathrm{mcg}$. Operasi berlangsung selama 1 jam 15 menit, dengan perdarahan 350 cc, hemodinamik stabil. Lahir bayi laki-laki, BB 3400 gr, PB $51 \mathrm{~cm}$, APGAR Score 8-9-10, Anus $(+)$. Pasien mencapai Bromage 0 pukul 00.15, kesadaran compos mentis, tekanan darah 148/95 $\mathrm{mmHg}$, denyut nadi 76x/menit, laju nafas 20x/menit, $\mathrm{SpO}_{2}: 98 \%$ dengan nasal kanul $3 \mathrm{lpm}$. Analgetik post operasi fentanyl $0,5 \mathrm{mcg} / \mathrm{kgbb} / \mathrm{jam}$ dan parasetamol $1 \mathrm{~g} / 8 \mathrm{jam} / \mathrm{IV}$.

\section{Pembahasan}

Preeklampsia adalah penyakit multiorgan yang spesfik terhadap kehamilan manusia. Meskipun pemahaman mengenai patofisiologi telah berkembang pesat namun etiologi spesifik yang mendasari tetap belum diketahui. Tatalaksana bersifat suportif, melahirkan bayi dan plasenta tetap menjadi satu-satunya terapi definitif. ${ }^{6-9}$ Pasien obesitas memiliki banyak implikasi klinis untuk dipertimbangkan dalam tatalaksana anestesi. Pemahaman mengenai patofisiologi akan membantu memberikan tatalaksana anestesi yang lebih baik. ${ }^{10-15}$ 
Penilaian jalan napas dan persiapan menghadapi intubasi sulit harus dilakukan secara seksama karena kemungkinan jalan napas sulit lebih tinggi akibat adanya edema general serta adanya penyulit morbid obese. ${ }^{7,8}$ Tekanan darah sistemik dapat berubahdrastis pada preeklampsiaberatbaik akibat penyakitnya maupun respon terhadap pemberian cairan dan obat antihipertensi. Sebagai tambahan preeklamsia berhubungan dengan penurunan volume intravaskular dan penilaian status volume intravaskular dapat menjadi kesulitan. Pemantauan hemodinamik secara invasif tidak mutlak diperlukan pada pasien preeklampsia namun terindikasi sesuai dengan indikasi pada disfungsi multiorgan penyakit lain. ${ }^{7-9}$ Pemilihan teknik neuraksial analgesia/anestesi lebih direkomendasikan karena menghindari kemungkinan intubasi sulit pada kasus emergensi, benefit dari perfusi uteroplasenta, kualitas analgesi/anestesia yang baik, mengurangi obatobatan yang masuk ke sirkulasi uteroplasenta, menurunkan stress operasi, dan psikologis ibu yang dapat melihat bayinya saat dilahirkan. ${ }^{7-9}$

\section{Simpulan}

Status Hipertensi pada kehamilan meliputi beberapa keadaan meliputi Preeklamsia, eklamsia, Hipertensi Kronik (Penyebab dasar lain atau sekunder karena penyakit ginjal, penyakit endokrin, atau penyebab-penyebab lain), Hipertensi kronik dengan Superimposed preeklamsia dan Gestasional Hipertensi. Pasien obesitas memiliki banyak implikasi klinis untuk dipertimbangkan dalam tatalaksana anestesi. Pemahaman mengenai patofisiologi akan membantu memberikan tatalaksana anestesi yang lebih baik. Penilaian jalan napas dan persiapan menghadapi intubasi sulit harus dilakukan secara seksama karena kemungkinan jalan napas sulit lebih tinggi akibat adanya edema general serta adanya penyulit morbid obese. Penyebab pasti dari Preeklamsia masih belum pasti diketahui. Namun tampaknya berkaitan dengan metabolisme prostaglandin abnormal dan disfungsi endotel yang menyebabkan hipereaktivitas vaskuler. Pasien dengan Pregnancy Induce Hypertension (PIH) memiliki kadar tromboksan A2 (TXA2) yang meningkat dan penurunan produksi prostasiklin (PGI2). TXA2 merupakan vasokonstriktor poten dan memicu agregasi platelet, di mana PGI2 merupakan vasodilatorpoten dan penghambat agregasi platelet. Disfungsi endotel dapat menurunkan produksi nitrit oksida dan meningkatkan produksi endothelin-1. Yang terakhir merupakan vasokonstriktor poten dan activator platelet. Prinsip prinsip umum manajemen preeklamsia meliputi restriktif terapi cairan, pengetahuan mengenai ekspansi volume plasma, penanganan hipertensi, pencegahan kejang, serta bagaimana seorang ahli amestesi memutuskan untuk diakhirinya kehamilan. Pilihan anestesi pada pasien yang telah diputuskan untuk terminasi kehamilan dapat ditentukan berdasarkan kondisi klinis pasien dengan beberapa macam pilihan diantaranya dengan regional anestesi baik dengan spinal anestesi ataupun epidural anestesi. Namun bila memang tidak memungkinkan untuk dilakuka dengan regional anestesi, pilihan untuk general anestesi dalam hal ini tetap memiliki tempat untuk diputuskan.

\section{Daftar Pustaka}

1. Bateman BT, Polley LS. Hypertensive disorder. Dalam: Chesnut DH, editor. Chesnut's Obstetric Anesthesia: Principles and Practice. 5th ed. Philadelphia: Saunders Elsevier; 2014; 825-59.

2. Baysinger CL. Hypertensive disorder of pregnancy. Dalam: Atlee JL, editor. Complications in Anesthesia. 2nd ed. Philadelphia: Saunders Elsevier. 2007; 59-62.

3. Bisri T. Obstetri Anesthesi. FK UNPAD Edisi 2 Bandung. 1998; 83-99.

4. David CH, Chintya W, Lawrence T, Beilin Yaakov B. Chesnut's Obstetric Anesthesia: Principles and Practice. Elsevier. Philadelphia. USA. 2014.

5. Cunningham FG, Leveno KJ, Bloom SL, Hauth J, Gilstrap LC, Wenstrom KD. HipertensiveDisordersinPregnancy. Williams Obstetric. ed 22th., McGraw-Hill. 2007. 
6. Cunningham FG, Twickler D. Cerebral edema complication eclampsia. Am J Obstet Gynecol. 2000; 182: 94-100.

7. Gatut DP, Suwondo BS. Seksio sesarea pada Eklamsia dan Preeklamsi. Dalam: Anestesi Obstetri. Komisi Pendidikan Spesialis Anestesiologi Konsultan Anestesi Obstetri. Saga Olahcitra. 2013; 133-51.

8. Gist R, Beilin Y. Hypertensive Disorders of Pregnancy., A Practical Approach to Obstetric Anesthesia, ed 1st., Lippincott Williams \& Wilkins. 2009; 350-63.

9. Turner JA. Diagnosis and management of pre-eclampsia: An update. International Journal of Women`s Health. 2010; 327-37.

10. Sellmann S. An effective solution to the obesity epidemic. Nexus Mag 2010;17:4..

11. American College of Obstetricians and
Gynecologists. ACOG Committee Opinion number 315, Obesity in pregnancy. ObstetGynecol 2005;106:671-5.

12. Ogden CL, Cerrol MD. Prevelance of overweight and obesity in united states 19992004. JAMA 2006; 295:1549-55.

13. Knight M, Kurinczuk JJ, Spark P, Brocklehurst P. UK Obstetric Surveillance System. Extreme obesity in pregnancy in the United Kingdom. Obstet Gynecol 2010; 115:989-97.

14. Saravanakumar K, Rao SG, Cooper GM. Obesity and obstetric anaesthesia. Anaesthesia 2006;61:36-48.

15. Benumof JL. Obstructive sleep apnoea in the adult obese patient: implications for airway management. J Clin Anesth 2001;13:144-56. 